\title{
HUBUNGAN STRATEGI REKRUTMEN TENAGA PENDIDIK DAN PENGHARGAAN PRESTASI TERHADAP MOTIVASI KERJA DI SANGGAR GENIUS YATIM MANDIRI MAKASSAR
}

\author{
ISMAN MUHLIS, M. YUSUF TAHIR, MARDYAWATI \\ Universitas Islam Negeri Alauddin Makassar \\ Email: ismanmuhlis2@gmail.com
}

\begin{abstract}
:
This research discuss the relation between teacher recruitment strategies and achievement awards toward work motivation at Sanggar Genius Yatim Mandiri Makassar with the aims: 1) to find out the teacher's recruitment strategies at Sanggar Genius Yatim Mandiri Makassar; 2) to discover the teacher's achievement awards Sanggar Genius Yatim Mandiri Makassar; 3) to determine the work motivation Sanggar Genius Yatim Mandiri Makassar; 4) to examine the correlation between teacherss recruitment and work motivation at Sanggar Genius Yatim Mandiri Makassar; 5) to examine the correlation between achievement awards and work motivation at Sanggar Genius Yatim Mandiri Makassar; and 6) to examine the correlation between the teacher's recruitment, the achievement of work motivation toward work motivation at Sanggar Genius Yatim Mandiri Makassar. This research is a quantitative by ex post facto method. Instrument used is a questionarre than analyzed by using product moment correlation. This research indicate that: 1) the teacher's recruitment strategy was in the very good category of the criteria set; 2) achievement awards for teachers were in the medium category 3) the teachers work motivation was in the medium category 4) the correlation between recruitment and selection of educators with work motivation showed a positive at a strong relation level; 5) the correlation between achievement awards for teachers with work motivation showed a positive and significant correlation at a moderate level of relation; 6) the correlation between recruitment and selection of teachers and achievement awards together with work motivation showed a positive and significant correlation at a strong relation level.
\end{abstract}

Keywords: Recruitment, Achievement Awards, Work Motivation

\section{PENDAHULUAN}

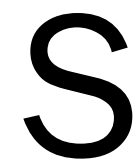
ekolah sebagai suatu institusi atau lembaga pendidikan merupakan sarana untuk melaksanakan proses pengembanagan karakter peserta didik. Sekolah bukan hanya dijadikan sebagai tempat berkumpul bagi guru dan siswa melainkan suatu sistem yang kompleks dan dinamis. Visi, misi dan tujuan diperlukan agar pengelolaan sekolah terarah dengan jelas. Bisa saja sekolah yang memiliki guru yang berkualitas, sarana dan prasarana yang memadai, siswa yang kualitasnya diatas rata-rata tetapi gagal dalam mewujudkan Iulusan yang berkualitas. Tenaga pendidik merupakan salah satu unsur terpenting dalam meningkatkan mutu pendidikan. Tenaga kependidikan adalah anggota masyarakat yang mengabdikan diri dan diangkat untuk menunjang penyelenggaraan pendidikan, yang meliputi 
pengelola satuan pendidikan, pamong belajar, pengawas, peneliti, pengembang, pustakawan, laboran dan teknisi sumber belajar.

Pentingnya peran tenaga pendidik, maka perlu adanya strategi rekrutmen yang bisa menghasilkan calon-calon tenaga pendidik yang profesional. Rekrutmen pendidik adalah seperangkat kegiatan dan proses yang dipergunakan untuk memperoleh sejumlah orang yang bermutu pada tempat dan waktu yang tepat sesuai dengan ketentuan hukum yang berlaku sehingga orang dan sekolah dapat saling menyeleksi berdasarkan kepentingan terbaik masing-masing dalam jangka panjang maupun jangka pendek (Putri Amalia, 2008:8). Pelaksanaan rekrutmen yang baik diharapkan sekolah mendapat tenaga pendidik yang sesuai dengan kualifikasi yang ditetapkan sekolah, karena di dalam keberlangsungan kegiatan sekolah unsur manusia merupakan unsur yang sangat penting, karena kelancaran jalannya pelaksanaan program sekolah sangat ditentukan oleh orang-orang yang terlibat di dalamnya. Permasalahan yang sering terjadi dalam rekrutmen tenaga pendidik yaitu masalah perencanaan rekrutmen yang kurang baik, sehingga sering terjadi kegagalan dalam pencapain tujuan sekolah karena banyak pekerjaanpekerjaan yang harusnya dilakukan oleh beberapa orang harus dikerjakan sendiri. Hal ini disebabkan oleh banyak faktor, salah satunya adalah kurangnya motivasi guru sehingga dalam melakukan pekerjaannya tidak memberikan kinerja yang maksimal.

Motivasi diartikan sebagai kekuatan, dorongan, semangat, tekanan, atau mekanisme psikologi yang mendorong seseorang atau sekelompok orang untuk mencapai prestasi tertentu sesuai apa yang dikehendakinya (Sudarwan Danin, 2004:4). Adapun faktor yang mempengaruhi motivasi kerja salah satunya adalah penghargaan prestasi. Penghargaan prestasi adalah sesuatu yang di berikan oleh kepala sekolah baik berupa materi maupun non materi. Maka dalam hal ini peran kepala sekolah dan lembaga sangat penting guna menciptakan suasana yang nyaman dan membangkitkan semangat saat bekerja, atau dengan kata lain bagaimana kepala sekolah dan lembaga mempunyai visi dan misi yang jelas. Penghargaan prestasi yang diberikan oleh pihak Yatim Mandiri terhadap tenaga pendidik terkadang tidak sesuai dengan apa yang diharapkan tenaga pendidik. Dengan demikian akan mempengaruhi system pembelajaran di sanggar genius Yatim Mandiri. Sehubungan dengan hal tersebut. Penelitian yang dilakukan Hesti Murwati, 2019:12 tentang pengaruh sertifikasi profesi guru terhadap motivasi kerja dan kinerja guru di smk negeri se-surakarta. Hasil penelitiannya menunjukkan bahwa terdapat pengaruh sertifikasi profesi guru terhadap motivasi kerja. Sejalan juga dengan Penelitian Siti Patimah, 2015:10, pengaruh rekrutmen dan seleksi terhadap kinerja kepala Madrasah Ibtidaiyah Negeri (MIN) se-Kota Bandar Lampung. Hasil penelitiannya menunjukkan bahwa terdapat korelasi terhadap rekrutmen dan seleksi guru dalam meningkatkan kinerja.

Penelitian ini lebih mengfokuskan pada strategi rekrutmen dan seleksi, penghargaan prestasi terhadap motivasi kerja, dan tujuan dari penelitian ini adalah 
untuk mendeskripsikan strategi rekrutmen dan seleksi tenaga pendidik, untuk mendeskripsikan penghargaan prestasi bagi tenaga pendidik, untuk mendeskripsikan motivasi kerja tenaga pendidik, untuk mengetahui hubungan yang signifikan antara rekrutmen tenaga pendidik dengan motivasi kerja, untuk mengetahui hubungan yang signifikan antara penghargaan prestasi dengan motivasi kerja, untuk mengetahui hubungan yang signifikan antara rekrutmen tenaga pendidik, penghargaan prestasi terhadap motivasi kerja di Sanggar Genius Yatim Mandiri Makassar.

\section{Rekrutmen dan Seleksi}

Dikutip Syukur, Dale Yoder mengatakan bahwa rekrutmen merupakan penarikan pegawai mencakup identifikasi dan evaluasi sumber-sumbernya, tahapan dalam proses keseluruhan menjadi untuk organisasi, kemudian dilanjutkan dengan mendaftar kemampuan penarikan, seleksi, penempatan, serta orientasi (Fatah Syukur, 2012: 67). Ahli manajemen sumber daya manusia memberikan berbagai macam definisi mengenai rekrutmen yaitu sebagai berikut; (Herman Sofyandi, h.100).

a. Proses menarik orang-orang atau pelamar yang mempunyai minat dan kualifikasi yang tepat untuk mengisi posisi atau jabatan tertentu.

b. Proses mencari dan mendorong calon karyawan untuk melamar pekerjaan dalam organisasi.

c. Proses yang dilakukan oleh suatu organisasi untuk mendapatkan tambahan karyawan.

Secara umum, tujuan penarikan tenaga kerja adalah untuk memenuhi kebutuhan tenaga kerja sesuai dengan persyaratan yang dituntut suatu pekerjaan. Secara khusus, tujuan penarikan tenaga kerja (Wilson Bangun, 2014:144) antara lain:

a. Agar sesuai dengan program dan strategi perusahaan. Sebelum melaksanakan kegiatannya, perusahaan terlebih dahulu menetapkan program dan strategi untuk mencapai sasaranya. Untuk merealisasikan program dan strategi perusahaan melakukan penarikan tenaga kerja sesuai kebutuhannya.

b. Untuk menentukaan kebutuhan tenaga kerja dalam jangka pendek dan panjang, berkaitan dengan perubahan dalam perusahaan, perencanaan sumber daya manusia, rancangan pekerjaan, dan analisis pekerjaan.

c. Untuk mendukung kebijaksanaan perusahaan dalam mengelola sumber daya manusia yang beragam.

d. Membantu dalam meningkatkan keberhasilan proses pemilihan tenaga kerja dengan mengurangi calon karyawan yang jelas tidak memenuhi syarat menjadi karyawan.

e. Mengurangi kemungkinan keluarnya karyawan yang baru bekerja. 
f. Sebagai upaya dalam mengkoordinasikan penarikan dengan program pemilihan dan pengembangan tenaga kerja.

g. Melakukan evaluasi efektif tidaknya berbagai teknik yang dilakukan dalam penarikan tenaga kerja.

Seleksi adalah proses identifikasi dan pemilihan orang-orang dari sekelompok pelamar yang paling cocok atau yang paling memenuhi syarat untuk menduduki suatu jabatan atau posisi tertentu. Dikutip (Handoko, 2001:85) Menurut Casiso, tujuan dari setiap program adalah untuk mengidentifikasi para pelamar yang memiliki skor tinggi pada berbagai aspek yang diukur, yang bertujuan menilai pengetahuan, keterampilan, kemampuan dan karakteristik lain yang penting untuk menjalankan suatu pekerjaan dengan baik. Proses seleksi yaitu dilakukan setelah kegiatan rekrutmen berakhir. Seleksi SDM merupakan sebuah proses untuk memilih dan menetapkan sejumlah orang dari calon-calon yang tersedia, dengan preferensi tertentu. Menurut T. Hani Handoko, proses seleksi tergantung pada 3 masukan penting. Informasi analisis jabatan memberikn deskripsi jabatan, spesifikasi jabatan dan standar-stadar prestasi yang disyaratkan setiap jabatan, rencana-rencana sumber daya manusia memberikan kepada manajer personalia bahwa ada lowongan kerja. Akhirnya, penarikan perlu agar manajer personalia harus menghadapi sekelompok yang dipilih.

\section{Pendidik}

Secara terminologi, pengertian yang lebih implisit kata pendidik dapat diartikan dengan guru, sebagaimana yang disampaikan oleh Hadari Nawawi yang dikutip oleh (Uzer, 2008:210) pendidik adalah orang yang kerjanya mengajar atau memberikan pelajaran di sekolah atau di kelas. Bahwa guru yang berarti orang yang bekerja sebagai tenaga pengajar yang ikut juga bertanggung jawab dalam membantu peserta didik untuk mencapai proses kedewasaan. Tetapi dalam hal ini banyak disalah artikan banyak orang, bahwa hanya gurulah yang bertanggung jawab dalam proses pendidikan. Tetapi yang sesungguhnya adalah baik masyarakat lebih-lebih orang tua peserta didik bersama-sama membangun proses pendidikan, agar menjadi masyarakat yang dewasa pula.

Menjadi seorang pendidik/guru memang berat, tetapi luhur dan mulia. Tugas guru tidak hanya mengajar tetapi juga mendidik. Sebagai guru yang baik harus memenuhi syarat-syarat yang ada di dalam Undang-undang No. 12 tahun 1954 tentang Dasar-dasar Pendidikan dan Pengajaran di sekolah untuk seluruh Indonesia, pada pasal 15. Dari pasal tersebut, maka syarat-syarat untuk menjadi guru dapat disimpulkan yakni: (a) berijazah; (b) sehat jasmani dan rohani; (c) takwa kepada Tuhan Yang Maha Esa dan berkelakuan baik; (d) bertanggung jawab; (e) berjiwa nasional (Ngalim Purwanto, 2006:139). 


\section{Penghargaan Prestasi}

Proses belajar mengajar merupakan inti dari kegiatan pendidikan di sekolah. Agar tujuan pendidikan dan pengajaran berjalan dengan lancar, maka seorang pendidik perlu melakukan usaha-usaha yang ditujukan dalam pelaksanaan tugas pendidikannya. Adapun usaha tersebut adalah dengan pemberian reward (ganjaran) yang merupakan salah satu alat pendidikan. (Purwanto,177) membagi alat pendidikan kepada 6 bagian yang dirangkaikan menjadi 3 bagian, yaitu: pembiasaan dan pengawasan, perintah dan larangan, ganjaran dan hukuman. Dalam hal ini dapat dipahami bahwa reward adalah hal atau sesuatu yang dapat menyenangkan hati seseorang yang diterima setelah ia melakukan hasil kerja yang baik dan membuatnya lebih termotivasi untuk berbuat yang lebih baik lagi.

Menurut (Alex Sobur, 1986:219) reward (ganjaran) yang diberikan seorang guru kepada siswa dalam proses belajar mengajar dapat berupa: pemberian hadiah, pemberian pujian, dan pemberian sikap menghargai. Sebagaimana pendekatanpendekatan pendidikan lainnya, pendekatan reward (ganjaran) juga tidak bisa terlepas dari kelebihan dan kekurangan. Dimana kelebihannya adalah Memberikan pengaruh yang cukup besar terhadap jiwa anak didik untuk melakukan perbuatan yang positif dan bersifat progresif dan untuk kelemahannya sendiri adalah apabila guru melakukannya secara berlebihan, sehingga mungkin bisa mengakibatkan murid menjadi merasa bahwa dirinya lebih tinggi dari teman-temannya.

\section{Motivasi Kerja}

Seseorang akan menentukan suatu keputusan atau pilihan yang diambil, maka ada sesuatu yang menjadi daya tarik dari apa yang dipilih dan merupakan unsur yang merangsang seseorang sehingga ia bekerja, sehingga seseorang memilih suatu bidang tertentu dalam bekerja, yang berbeda dengan pilihan orang lain atau mungkin juga sama. Adanya pilihan tersebut menunjukkan bahwa ada indikasi motif tertentu dalam memilih.

Setiap motif mempunyai tujuan tertentu yang ingin dicapai. Sedangkan motivasi berasal dari kata movere yang berarti dorongan, dalam istilah bahasa Inggrisnya disebut motivation. Motivasi dapat didefinisikan sebagai suatu usaha yang menimbulkan dorongan (motif) pada individu (kelompok) agar bertindak (Robbins, 1988:28). Motivasi ada hubungannya dengan jenis atau peringkat kebutuhan manusia. Apabila seseorang bekerja, karena ada motif tertentu di belakang atau di balik kerjanya. Faktor yang menjadi pendorong umum dinamakan faktor motivasi. Semua faktor tersebut pada dasarnya merupakan bentuk-bentuk motif yang mendorong seseorang melakukan pekerjaannya secara sungguh-sungguh. Dalam hubungannya itu Hadari Nawawi membedakan dua jenis motif, yakni: a) Motif intrinsik yaitu dorongan yang terdapat dalam pekerjaan yang dilakukan. Misalnya, bekerja karena pekerjaan itu sesuai dengan bakat dan minat, dapat diselesaikan dengan baik karena memiliki pengetahuan dan keterampilan dalam 
menyelesaikannya dan lain-lain, b) Motif ekstrinsik yaitu dorongan yang berasal dari luar pekerjaan yang sedang dilakukan. Misalnya, bekerja karena upah atau gaji yang tinggi, merasa mulia karena pengabdian dan sebagainya.

\section{Hipotesis}

Hipotesis dalam penelitian ini merupakan hipotesis asosiatif yang menanyakan hubungan antara dua variabel atau lebih. Adapun hipotesis dalam penelitian ini, yaitu:

a. Terdapat hubungan yang signifikan antara strategi rekrutmen dengan motivasi kerja di Sanggar Genius Yatim Mandiri Makassar.

b. Terdapat hubungan yang signifikan antara penghargaan prestasi dengan motivasi kerja di Sanggar Genius Yatim Mandiri Makassar.

c. Terdapat hubungan yang signifikan antara strategi rekrutmen, penghargaan prestasi dengan motivasi kerja Sanggar Genius Yatim Mandiri Makassar.

\section{METODOLOGI PENELITIAN}

Jenis penelitian yang digunakan penulis adalah penelitian lapangan (field research) dengan menggunakan penelitian korelasional sebagai bagian dari penelitian kuantitatif. Penelitian korelasi adalah suatu penelitian yang melibatkan tindakan pengumpulan data untuk menentukan hubungan/pengaruh dan tingkat hubungan antara dua variabel atau lebih (Sukardi, 2013:166). Penelitian korelasi adalah suatu penelitian yang melibatkan tindakan pengumpulan data untuk menentukan hubungan/pengaruh dan tingkat hubungan antara dua variabel atau lebih. Penelitian dilaksanakan di Sanggar Genius Yatim Mandiri Makassar beralokasikan di J. Andi Tonro No. 11 Kecamatan Tamalate Kelurahan Pa'Baengbaeng Kota Makassar.

Pendekatan diartikan sebagai usaha dalam aktivitas peneliti dalam melakukan penelitian untuk mengadakan hubungan-hubungan dengan obyek yang ditelitinya (Suharismi Arikunto, 2010:8). Pendekatan yang digunakan dalam penelitian ini dapat dibedakan menjadi dua, yakni pendekatan metodologi dan pendekatan keilmuan.

Adapun yang menjadi populasi penelitian ini, yaitu seluruh guru di Sanggar Genius Yatim Mandiri Makassar dimana sebanyak 21 orang guru yang terdiri dari 6 orang laki-laki dan 15 orang perempuan. Populasi tersebut diambil dari keseluruhan guru yang ada pada Sanggar Genius Yatim Mandiri Makassar. Dalam menentukan sebuah sampel dalam penelitian ini, peneliti menggunakan sampel jenuh, yaitu teknik penentuan sampel bila semua anggota populasi digunakan sebagai sampel. $\mathrm{Hal}$ ini sering dilakukan bila jumlah populasi relatif kecil, kurang dari 30 orang, atau penelitian yang ingin membuat generalisasi dengan kesalahan yang sangat kecil (Sugiyono, 2016:85). Oleh karena itu, sampel dalam penelitian ini adalah semua guru Sanggar Genius Yatim Mandiri Makassar. yang berjumlah 21 orang. 
Teknik pengumpulan data dalam penelitian merupakan langkah yang sangat strategis, sebab tujuan utama dalam melakukan penelitian adalah memperoleh data. Sehingga teknik pengumpulan yang digunakan dalam penelitian ini adalah berupa angket. Angket disusun berdasarkan indikator dari setiap dimensi variabel penelitian ini kemudian diedarkan kepada seluruh guru di Sanggar Genius Yatim Mandiri Makassar. Teknik pengelolaan dan analisis data yang digunakan dalam penelitian ini adalah teknik scoring, penyajian data dalam bentuk distribusi frekuensi dan perhitungan rata-rata mean score yang diinterpretasikan ke dalam kategori yang telah ditentukan. Adapun pengujian hipotesis yang dilakukan dengan menggunakan analisis korelasi product moment yang hasilnya dinterpretasikan ke dalam nilai koefisien korelasi yang telah ditentukan.

\section{HASIL PENELITIAN}

Deskripsi strategi rekrutmen dan seleksi tenaga pendidik di Sanggar Genius Yatim Mandiri Makassar

Rata-rata tanggapan responden diinterpretasikan pada pedoman konversi nilai dengan ketentuan: Jumlah pernyataan $=20$; jumlah alternatif jawaban $=5$ (berdasarkan skala Likert); skor maksimal setiap item $=5$ sehingga skor kriterium (ideal) $=20 \times 5=100$ dan skor minimum setiap item $=1$ sehingga skor terendah yang mungkin diperoleh $=20 \times 1=20$. Dengan demikian, range $=100-20=80$ dan interval kelas $=80 / 5=16$ sehingga dapat dibuat tabel seperti berikut ini:

Tabel 1 Data rekrutmen tenaga pendidik di Sanggar Genius Yatim Mandiri Makassar

\begin{tabular}{|c|c|c|c|}
\hline Interval & Kategori & Frekuensi & Persentase \\
\hline $20-36$ & Sangat tidak baik & 0 & $0 \%$ \\
\hline $37-52$ & Tidak baik & 0 & $0 \%$ \\
\hline $53-68$ & Sedang & 0 & $0 \%$ \\
\hline $69-84$ & Baik & 2 & $9,52 \%$ \\
\hline $85-100$ & Sangat baik & 19 & $90,48 \%$ \\
\hline Jumlah & - & $\mathbf{2 1}$ & $100 \%$ \\
\hline
\end{tabular}

Berdasarkan tabel tersebut dapat diketahui bahwa rata-rata tanggapan dari 21 responden yaitu 93,52 berada pada interval 85-100 dengan jumlah frekuensi sebanyak 19 orang dan persentase sebesar 90,48\% yang memberikan paham bahwa rekrutmen tenaga pendidik di Sanggar Genius Yatim Mandiri Makassar berada pada kategori sangat baik.

\section{Deskripsi Sistem Penghargaan Prestasi Bagi Tenaga Pendidik di Sanggar Genius Yatim Mandiri Makassar}

Rata-rata tanggapan responden diinterpretasikan pada pedoman konversi. Berdasarkan tabel tersebut dapat diketahui bahwa rata-rata tanggapan dari 21 
responden yaitu 46,33 berada pada interval 53-68 dengan jumlah frekuensi sebanyak 12 orang dan persentase sebesar 57,14\% yang memberikan paham bahwa penghargaan prestasi bagi tenaga pendidik di Sanggar Genius Yatim Mandiri Makassar berada pada kategori sedang.

Tabel 2 Data penghargaan prestasi bagi tenaga pendidik di Sanggar Genius Yatim Mandiri Makassar

\begin{tabular}{|c|c|c|c|}
\hline Interval & Kategori & Frekuensi & Persentase \\
\hline $20-36$ & Sangat tidak baik & 0 & $0 \%$ \\
\hline $37-52$ & Tidak baik & 9 & $42,86 \%$ \\
\hline $53-68$ & Sedang & 12 & $57,14 \%$ \\
\hline $69-84$ & Baik & 0 & $0 \%$ \\
\hline $85-100$ & Sangat baik & 0 & $0 \%$ \\
\hline Jumlah & - & 21 & $100 \%$ \\
\hline
\end{tabular}

\section{Deskripsi gambaran motivasi kerja tenaga pendidik di Sanggar Genius Yatim Mandiri Makassar}

Rata-rata tanggapan responden diinterpretasikan pada pedoman konversi. Berdasarkan tabel tersebut dapat diketahui bahwa rata-rata tanggapan dari 21 responden yaitu 67,62berada pada interval 53-68 dengan jumlah frekuensi sebanyak 13 orang dan persentase sebesar 61,90\% yang memberikan paham bahwa motivasi kerja tenaga pendidik di Sanggar Genius Yatim Mandiri Makassar berada pada kategori sedang

Tabel 3 Data motivasi kerja tenaga pendidik di Sanggar Genius Yatim Mandiri Makassar

\begin{tabular}{|c|c|c|c|}
\hline Interval & Kategori & Frekuensi & Persentase \\
\hline $20-36$ & Sangat tidak baik & 0 & $0 \%$ \\
\hline $37-52$ & Tidak baik & 0 & $0 \%$ \\
\hline $53-68$ & Sedang & 13 & $61,90 \%$ \\
\hline $69-84$ & Baik & 8 & $38,1 \%$ \\
\hline $85-100$ & Sangat baik & 0 & $0 \%$ \\
\hline Jumlah & - & 21 & $100 \%$ \\
\hline
\end{tabular}

Teknik analisis data yang digunakan dalam analisis inferensial yaitu dengan melakukan uji prasyarat yakni uji normalitas data dan uji linearitas data sebelum pengujian hipotesis. Maka hasil dari uji prasyarat yakni uji normalitas adalah berdasarkan tabel output SPSS tersebut, dapat dipahami bahwa signifikansi Asymp. Sig. (2-tailed) untuk data rekrutmen memiliki nilai sebesar 0,204, data penghargaan prestasi memiliki nilai sebesar 0,268 dan data motivasi kerja memiiki nilai sebesar 0,588 yang menunjukkan lebih besar dari 0,05 selanjutnya memberikan asumsi bahwa data tersebut berdistribusi normal karena sesuai dengan dasar pengambilan keputusan dalam uji normalitas kolmogorov-smirnov Z yang menyatakan bahwa jika nilai signifikansi (Sig.) lebih besar dari 0,05 maka data penelitian berdistribusi 
normal. Dengan demikian, data yang diperoleh dari tanggapan responden di yatim mandiri makassar dapat dinyatakan berdistribusi normal. Sedangkan untuk hasil uji linearitas data adalah berdasarkan tabel output SPSS tersebut, dapat dilihat bahwa nilai signifikansi (Sig.) yang diperoleh dari deviation from linearity adalah lebih besar dari 0,05 maka dapat memberikan asusmsi bahwa data tersebut memiliki hubungan yang linear secara signifikansi.

\section{Korelasi Antara Rekrutmen dan Seleksi Tenaga Pendidik dengan Motivasi Kerja di Sanggar Genius Yatim Mandiri Makassar}

Berdasarkan tabel output SPSS version 20 tersebut dapat diketahui bahwa besarnya korelasi antara variabel rekrutmen tenaga pendidik dengan variabel motivasi kerja di Sanggar Genius Yatim Mandiri Makassar dapat dilihat pada pearson correlation adalah 0,680. 0,680 berada pada interval 0,60-0,799 yang menunjukkan tingkat hubungan yang kuat. Kemudian pada sig. (2-tailed) diperoleh nilai 0,001 yang menandakan nilai tersebut lebih kecil dari 0,05(dengan taraf signifikansi $5 \%$ ) yang artinya korelasi kedua variabel tersebut signifikan pada angka kepercayaan 99\% sehingga dapat dikatakan bahwa korelasi antara rekrutmen tenaga pendidik dengan motivasi kerja berlaku untuk seluruh populasi.

\section{Tabel 4 Korelasi antara Rekrutmen dan Seleksi Tenaga Pendidik dengan Motivasi}

\section{Kerja}

\begin{tabular}{|ll|r|r|}
\hline & & Rekrutmen & Motivasi Kerja \\
\hline \multirow{4}{*}{ Rekrutmen } & Pearson Correlation & 1 & $.680^{* *}$ \\
& Sig. (2-tailed) & & .001 \\
& $\mathrm{~N}$ & 21 & 21 \\
& Pearson Correlation & $.680^{* *}$ & 1 \\
Motivasi Kerja & Sig. (2-tailed) & .001 & \\
& $\mathrm{~N}$ & 21 & 21 \\
\hline
\end{tabular}

**. Correlation is significant at the 0.01 level (2-tailed).

\section{Korelasi antara penghargaan prestasi dengan motivasi kerja di Sanggar Genius} Yatim Mandiri Makassar

Berdasarkan tabel output SPSS version 20 tersebut dapat diketahui bahwa besarnya korelasi antara variabel penghargaan prestasi dengan variabel motivasi kerja di Sanggar Genius Yatim Mandiri Makassar dapat dilihat pada pearson correlation yaitu dengan nilai 0,509. 0,509 berada pada interval 0,40-0,599 yang menunjukkan korelasi yang sedang antar variabel. Kemudian pada sig. (2-tailed) diperoleh nilai 0,018 yang menandakan nilai tersebut lebih kecil dari 0,05(dengan taraf signifikansi 5\%) yang artinya korelasi kedua variabel tersebut signifikan pada angka kepercayaan 99\% sehingga dapat dikatakan bahwa korelasi antara penghargaan prestasi dengan motivasi kerja berlaku untuk seluruh populasi. 
Tabel 5 Korelasi antara Penghargaan Prestasi dengan Motivasi Kerja

\begin{tabular}{|ll|r|r|}
\hline & & $\begin{array}{l}\text { Penghargaan } \\
\text { Prestasi }\end{array}$ & $\begin{array}{l}\text { Motivasi } \\
\text { Kerja }\end{array}$ \\
\hline & $\begin{array}{l}\text { Pearson } \\
\text { Penghargaan }\end{array}$ & 1 & $.509^{*}$ \\
Prestasi & $\begin{array}{l}\text { Correlation } \\
\text { Sig. (2- }\end{array}$ & & .018 \\
& tailed) & 21 & 21 \\
& Pearson \\
& Correlation & $.509^{*}$ & 1 \\
Motivasi Kerja & Sig. (2- \\
& tailed) & .018 & \\
& $\mathrm{~N}$ & 21 & 21 \\
\hline
\end{tabular}

*. Correlation is significant at the 0.05 level (2-tailed).

\section{Korelasi Antara Rekrutmen dan Penghargaan Prestasi Secara Bersama-Sama Dengan Motivasi Kerja Di Sanggar Genius Yatim Mandiri Makassar}

Berdasarkan tabel output SPSS version 20 tersebut dapat diketahui bahwa besarnya korelasi antara variabel rekrutmen dan penghargaan prestasi secara bersama-sama dengan motivasi kerja di Sanggar Genius Yatim Mandiri Makassar adalah 0,777. 0,777 berada pada interval 0,60-0,799 yang menandakan bahwa terdapatnya korelasi yang kuat secara bersama-sama antara di Sanggar Genius Yatim Mandiri Makassar. Sehingga diperoleh nilai dari tabel 6 sig. $F$ change 0,000. Nilai sig. $F$ change $0,000<0,05$ menandakan bahwa $\mathrm{H}_{0}$ ditolak dan $\mathrm{H}_{1}$ diterima, sehingga dapat dikatakan bahwa rekrutmen dan penghargaan prestasi memiliki korelasi secara bersama-sama dan signifikan dengan motivasi kerja di Sanggar Genius Yatim Mandiri Makassar.

Tabel 6 Korelasi antara rekrutmen dan penghargaan prestasi secara bersamasama dengan motivasi kerja

Model Summary

\begin{tabular}{|c|c|c|c|c|c|c|c|c|c|}
\hline \multirow{2}{*}{$\begin{array}{l}\text { Mod } \\
\text { el }\end{array}$} & \multirow[t]{2}{*}{$\mathrm{R}$} & \multirow{2}{*}{$\begin{array}{c}\mathrm{R} \\
\text { Squar } \\
\mathrm{e}\end{array}$} & \multirow{2}{*}{$\begin{array}{c}\text { Adjuste } \\
\text { d R } \\
\text { Square }\end{array}$} & \multirow{2}{*}{$\begin{array}{c}\text { Std. } \\
\text { Error of } \\
\text { the } \\
\text { Estimate }\end{array}$} & \multicolumn{5}{|c|}{ Change Statistics } \\
\hline & & & & & $\begin{array}{c}\text { R } \\
\text { Square } \\
\text { Change }\end{array}$ & $\begin{array}{c}\mathrm{F} \\
\text { Chang } \\
\mathrm{e}\end{array}$ & df1 & $\mathrm{df} 2$ & $\begin{array}{c}\text { Sig. F } \\
\text { Chang } \\
\mathrm{e}\end{array}$ \\
\hline 1 & $.777^{a}$ & .603 & .559 & 3.840 & .603 & $\begin{array}{r}13.68 \\
8\end{array}$ & 2 & 18 & .000 \\
\hline
\end{tabular}

a. Predictors: (Constant), Penghargaan Prestasi, Rekrutmen 


\section{PEMBAHASAN}

\section{Strategi rekrutmen dan seleksi tenaga pendidik di Sanggar Genius Yatim Mandiri Makassar}

Setelah dilakukan analisis data, diketahui bahwa strategi rekrutmen dan seleksi tenaga pendidik di Sanggar Genius Yatim Mandiri Makassar berada pada kategori sangat baik dengan skor-skor maksimum yang diperoleh peserta didik adalah 100 sedangkan skor minimum adalah 79 dengan rata-rata sebesar 93,52. Standar deviasi sebesar 6,38. Berdasarkan tabel distribusi frekuensi, diperoleh bahwa terdapat 2 tenaga pendidik atau 9,52\% memiliki strategi rekrutmen tenaga pendidik yang baik dan 19 tenaga pendidik atau 90,48\% memiliki strategi rekrutmen dan seleksi tenaga pendidik yang sangat baik. Dengan demikian dapat disimpulkan bahwa skor startegi rekrutmen dan seleksi tenaga pendidik pada seluruh subjek penelitian ini termasuk kategori sangat baik.

Rekrutmen merupakan suatu proses untuk mendapatkan tenaga pendidik yang sesuai dengan kualifikasinya. (Herman Sofyandi Schermerho, 2013: 99) menyatakan, rekrutmen adalah proses penarikan sekelompok kandidat untuk mengisi posisi yang lowong yang tujuannya untuk menemukan orang-orang yang berkemampuan dan keterampilan memenuhi spesifikasi pekerjaan yang dibutuhkan.

\section{Korelasi antara rekrutmen dengan motivasi kerja di Sanggar Genius Yatim Mandiri Makassar}

Setelah dilakukan analisis data, diketahui bahwa prestasi bagi tenaga pendidik di Sanggar Genius Yatim Mandiri Makassar berada pada kategori sedang diketahui bahwa skor maksimum yang diperoleh peserta didik adalah 63 sedangkan skor minimum adalah 38 dengan rata-rata sebesar 50,52. Standar deviasi sebesar 6,55.Berdasarkan tabel distribusi frekuensi, diperoleh bahwa penghargaan prestasi bagi tenaga pendidik terdapat 9 tenaga pendidik dengan persentase 42,86\% berada pada kategori tidak baik dan 12 tenaga pendidik dengan persentase 57,14\% berada pada kategori sedang. Data dari tabel distribusi frekuensi penghargaan prestasi di sanggar genius yatim mandiri menunjukkan bahwa kecenderungan penghargaan prestasi berpusat pada kategori sedang. Dengan demikian dapat disimpulkan bahwa skor penghargaan prestasi pada seluruh subjek penelitian ini termasuk kategori sedang.

Reward adalah hal atau sesuatu yang dapat menyenangkan hati seseorang yang diterima setelah ia melakukan hasil kerja yang baik dan membuatnya lebih termotivasi untuk berbuat yang lebih baik lagi. Dalam proses pendidikan memberikan reward bebas dilakukan oleh siapapun dan dapat ditujukan kepada siapapun. Akan tetapi lain halnya dengan memberikan hukuman, hukuman tidak dapat dilakukan sewenang-wenang menurut kehendak seseorang, tetapi terikat oleh peraturan-peraturan tertentu. Senada dengan (Alex, 1986:219) reward (ganjaran) 
yang diberikan seorang guru kepada siswa dalam proses belajar mengajar dapat berupa: pemberian hadiah, pemberian pujian, dan pemberian sikap menghargai.

\section{Korelasi antara motivasi kerja tenaga pendidik di Sanggar Genius Yatim Mandiri Makassar}

Setelah dilakukan analisis data, diketahui bahwa motivasi kerja tenaga pendidik di Sanggar Genius Yatim Mandiri Makassar berada pada kategori sedang diketahui bahwa skor maksimum yang diperoleh peserta didik adalah 60 sedangkan skor minimum adalah 21 dengan rata-rata sebesar 67,62. Standar deviasi sebesar 5,78 . Berdasarkan tabel distribusi frekuensi, diperoleh bahwa motivasi kerja tenaga pendidik terdapat 13 tenaga pendidik dengan persentase $61,90 \%$ berada pada kategori sedang dan 8 tenaga pendidik dengan persentase $38,1 \%$ berada pada kategori baik. Data dari tabel distribusi frekuensi motivasi kerja di sanggar genius yatim mandiri menunjukkan bahwa kecenderungan motivasi kerja berpusat pada kategori sedang. Dengan demikian dapat disimpulkan bahwa skor penghargaan prestasi pada seluruh subjek penelitian ini termasuk kategori sedang.

Motivasi dapat didefinisikan sebagai suatu usaha yang menimbulkan dorongan (motif) pada individu (kelompok) agar bertindak (Stephen P. Robbins, 1988:28). Pendapat lain mengatakan bahwa motivasi ialah kehendak atau dorongan untuk melakukan sesuatu dalam rangka memenuhi kebutuhan yang dirasakan. Motivasi juga bisa diartikan sebagai proses yang menyebabkan tingkah laku seseorang menjadi bergairah, terarah, dan tidak mudah putus asa.

\section{Korelasi antara rekrutmen dan seleksi tenaga pendidik dengan motivasi kerja di Sanggar Genius Yatim Mandiri Makassar}

Analisis korelasi yang dilakukan pada bagian sebelumnya, memberikan asumsi bahwa terdapat korelasi antara rekrtmen dan seleksi tenaga pendidik dengan motivasi kerja di Sanggar Genius Yatim Mandiri Makassar.

Dikutip (Fatah Syukur, 2012:67), Dale Yoder mengatakan bahwa rekrutmen merupakan penarikan pegawai mencakup identifikasi dan evaluasi sumbersumbernya, tahapan dalam proses keseluruhan menjadi untuk organisasi, kemudian dilanjutkan dengan mendaftar kemampuan penarikan, seleksi, penempatan, serta orientasi. Tujuan rekrutmn itu sendiri adalah untuk mendapatkan persediaan sebanyak mungkin calon-calon pelamar sehingga organisasi akan mempunyai kesempatan yang lebih besar utuk melakukan pilihan terhadap calon pekerja yang dianggap memenuhi standar kualifikasi organsasi (Faustino Cardoso, 2003:105).

Pendapat yang dikemukakan oleh Dale Yoder tersebut, didukung oleh Ahli manajemen sumber daya manusia memberikan berbagai macam definisi mengenai rekrutmen yaitu salah satunya adalah Proses menarik orang-orang atau pelamar yang mempunyai minat dan kualifikasi yang tepat untuk mengisi posisi atau jabatan tertentu. Hal tersebut memberikan asumsi bahwa rekrutmen tenaga pendidik dapat memberikan pengaruh yang cukup besar terhadap motivasi kerja tenaga pendidik. 


\section{Korelasi antara penghargaan prestasi dengan motivasi kerja di Sanggar Genius Yatim Mandiri Makassar}

Analisis korelasi yang dilakukan pada bagian sebelumnya, memberikan asumsi bahwa terdapat korelasi antara penghargaan prestasi dengan motivasi kerja di Sanggar Genius Yatim Mandiri Makassar.

Hasil tersebut sejalan dengan teori (Alex, 1986:219) reward (ganjaran) yang diberikan seorang guru kepada siswa dalam proses belajar mengajar dapat berupa: pemberian hadiah, pemberian pujian, dan pemberian sikap menghargai. Oleh karena itu penghargaan prestasi yang dimaksudkan dalam penelitian ini adalah bagaimana pihak lembaga yang memberikan apresiasi berupa panghargaan prestasi dalam bentuk fee/bonus kepada tenaga pendidik agar dapat termotivasi dalam melakukan pekerjaannya. Seiing dengan apakah ada hubungan antara penghargaan prestasi dengan motivasi kerja dapat dilihat dalam analisis sebelumnya yang menunjukkan angka signifikasi yang lebih kecil dari angka signikafikasi yang telah ditentukan.

\section{Korelasi antara rekrutmen dan penghargaan prestasi secara bersama-sama dengan motivasi kerja di Sanggar Genius Yatim Mandiri Makassar}

Analisis korelasi yang dilakukan pada bagian sebelumnya, memberikan asumsi bahwa terdapat korelasi antara rekrutmen dan penghargaan prestasi secara bersama-sama dengan motivasi kerja di Sanggar Genius Yatim Mandiri Makassar.

Motivasi yang terdapat pada diri manusia atau tenga pendidik dapat dilihat dari bagaimana proses rekrutmen dan penghargaan prestasi yang diberikan dalam sebuah lembaga atau tempat naungan pekerjaan. Hubungan timbal balik yang dimaksud adalah rekrutmen yang dilakukan oleh pihak lembaga dengan melewati seleksi yang cukup panjang dan sehingga mendapatkan tenaga pendidik yang tepat sesuai dengan kriteria yang dibutuhkan. Selain rekrutmen, yang dibutuhkan setelah melakukan sebuah pekerjaan adalah penghargan baik itu berupa penghargaan yan tertulis, finansial ataupun sebgainya agar dapat tercipta suasana yang menyenangkan dalam lembaga yang dilihat dari perilaku-perilaku baik dari tenaga pendidik.

Mengingat pentingnya rekrutmen dan penghargaan prestasi tenaga pendidik dalam menciptakan motivasi kerja yang baik, peran kepala cabang dan seluruh pihak yang berkepentingan diharapkan dapat menciptakan rasa yang nyaman dalam bekerja agar lebih kondusif alam melaksanakan tugas dan tanggung jawab dapat dikerjakan dengan termotivasi bekerja yang aman, nyaman, dan menyenangkan sehingga pekerjaan dapat berjalan secara optimal dan pada akhirnya apa yang diinginkan dapat terwujud secara efektif dan efisien. 


\section{PENUTUP}

\section{Kesimpulan}

Penarikan kesimpulan penelitian dirumuskan berdasarkan hasil analisis dan pembahasan yang telah diuraikan pada bab sebelumnya. Kesimpulan penelitian ini adalah sebagai berikut:

1. Deskripsi strategi rekrutmen dan seleksi tenaga pendidik di Sanggar Genius Yatim Mandiri Makassar berada pada kategori baik sebanyak 9,52\%, dan pada kategori sangat baik sebanyak $90,48 \%$ sehingga secara umum startegi rekrutmen tenaga pendidik berada pada kategori sangat baik.

2. Deskripsi penghargaan prestasi bagi tenaga pendidik di Sanggar Genius Yatim Mandiri Makassar berada pada kategori tidak baik sebanyak 42,86\%, dan pada kategori sedang sebanyak $57,14 \%$ sehingga secara umum penghargaan prestasi bagi tenaga pendidik berada pada kategori sedang.

3. Deskripsi motivasi kerja tenaga pendidik di Sanggar Genius Yatim Mandiri Makassar berada pada kategori baik sebanyak 38,1\%, dan pada kategori sedang sebanyak $61,90 \%$ sehingga secara umum motivasi kerja tenaga pendidik berada pada kategori sedang.

4. Korelasi antara rekrutmen dan seleksi tenaga pendidik dengan motivasi kerja di Sanggar Genius Yatim Mandiri Makassar menunjukkan korelasi positif dan signifikan dengan nilai koefisien korelasi sebesar 0,680 berada pada tingkat hubungan yang kuat.

5. Korelasi antara penghargaan prestasi dengan motivasi kerja di Sanggar Genius Yatim Mandiri Makassar menunjukkan korelasi positif dan signifikan dengan nilai koefisien korelasi sebesar 0,509 berada pada tingkat hubungan yang sedang.

6. Korelasi antara rekrutmen dan seleksi tenaga pendidik dan penghargaan prestasi secara bersama-sama dengan motivasi kerja tenaga pendidik di Sanggar Genius Yatim Mandiri Makassar menunjukkan korelasi positif dan signifikan dengan nilai koefisien korelasi sebesar 0,777 berada pada tingkat hubungan yang kuat.

\section{Implikasi Penelitian}

Implikasi penelitian ini berisi saran-saran atau rekomendasi yang penulis pandang perlu untuk para pengelola lembaga. Adapun saran-saran yang penulis maksud, yaitu sebagai berikut:

1. Pihak lembaga baik itu kepala cabang, staf program, admin, sizco, relawan, guru, dan peserta didik hendaknya terus berupaya untuk memperbaiki cara rekrutmen dan seleksi yang lebih baik lagi serta lebih berupaya untuk menciptakan penghargaan prestasi yang dapat memberikan rasa yang semangat dengan memupuk kerja sama sehingga dapat melaksanakan tugas dan tanggung jawabnya dengan suasana yang menyenangkan yang pada akhirnya 
memberikan efek positif bagi lembaga tak terkecuali keberhasilan pada lembaga.

2. Pihak lembaga terkhusus tenaga pendidik hendaknya dapat menciptakan suasana yang kondusif agar dapat melaksanakan pembelajaran yang menyenangkan sehingga peserta didik dapat merasa senang dan lebih termotivasi untuk melaksanakan pembelajaran.

\section{DAFTAR PUSTAKA}

Amalia, Putri. 2010. Strategi Rekrutmen Tenaga Pendidik dan Kependidikan Pada Sekolah Dasar Islam Terpadu (SDIT) Darul Muttaqien Parung Bogor. Tesis.

Arikunto, Suharismi. 2010. Prosedur Penelitian: Suatu Pendekatan Praktik Cet. XI V; Jakarta: Rineka Cipta.

Bangun, Wilson. 2012. Manajemen Sumber Daya Manusia. Jakarta: Erlangga.

Cardoso, Faustino. 2003. Manajemen Sumber Daya Manusia. Yogyakarta: Andi.

Danin, Sudarwan. 2004. Motivasi Kepemimpinan \& Efektivitas Kelompok. Jakarta: PT Rineka Cipta.

Handoko T. Hani. 2001. Menajemen Personalia \& Sumberdaya Manusia. Yogyakarta: BPFE-Yogyakarta.

Murwati Hesti. 2019. Pengaruh sertifikasi profesi guru terhadap motivasi kerja dan kinerja guru di smk negeri se-surakarta 2013. Vol 1 No. 1. h.12, https://eprints.uns.ac.id/1083/1/1896\%2D4270\%2D1\%2DSM.pdf, diakses tanggal 25 Juni 2019.

Patimah, Siti. 2015. Pengaruh Rekrutmen dan Seleksi terhadap Kinerja Kepala Madrasah Ibtidaiyah Negeri (MIN) se-Kota Bandar Lampung. 2015. Vol. 3 No. 1,h.10,https://www.journal.scadindependent.Org/index.php/jipeuradeun/art icle/view/62, di akses tanggal 27 September 2019.

Purwanto, Ngalim. 2006. IImu Pendidikan Teoretis dan Praktis. Bandung: Remaja Rosdakarya.

Robbins, Stephen P. 1988. Perilaku Organisasi: Versi Bahasa Indonesia. edisi Kedelapan Jilid 1, Jakarta: PT Prenhallindo.

Sugiyono. 2016. Metode Penelitian Kuantitatif, Kualitatif, R\&D. Cet. XXI; Bandung: Alfabeta.

Sukardi. 2013. Metode Penelitian Pendidikan Cet. XII; Jakarta: Bumi Aksara, 2013

Sofyandi, Herman. 2013. Manajemen Sumber Daya Manusia. Jogjakarta: Graha IImu.

Syukur Fatah. 2012. Manajemen Sumber Daya Manusia Pendidikan. Semarang: Pustaka Rizki Putra.

Usman, Moh. Uzer. 2008. Menjadi Guru Profesional. Bandung: Remaja Rosdakarya. 